\title{
Brain serotonin-2 receptors in acute mania
}

Lakshmi N. Yatham, Peter F. Liddle, Jonathan Erez, Marcia Kauer-Sant'Anna, Raymond W. Lam, Miguel Imperial, Vesna Sossi and Thomas J. Ruth

\section{Background}

Although 5-hydroxytryptamine (5-HT) has been implicated in mania, the precise alterations in the 5-HT system remain elusive.

\section{Aims \\ To assess brain $5-\mathrm{HT}_{2}$ receptors in drug-free individuals experiencing a manic episode in comparison with healthy volunteers using positron emission tomography (PET).}

\section{Method}

Participants $(n=10)$ with DSM-IV bipolar I disorder - manic episode and healthy controls $(n=10)$ underwent $\left[{ }^{18} \mathrm{~F}\right]$ setoperone scans. The differences in $5-\mathrm{HT}_{2}$ receptor binding potential between the two groups were determined using statistical parametric mapping (SPM) analysis.

\section{Results}

Age was a significant correlate with $5-\mathrm{HT}_{2}$ receptor binding potential with a similar magnitude of correlation in both groups. The SPM analysis with age as a covariate showed that the individuals with current mania had significantly lower $5-\mathrm{HT}_{2}$ receptor binding potential in frontal, temporal, parietal and occipital cortical regions, with changes more prominent in the right cortical regions compared with controls.

\section{Conclusions}

This study suggests that brain $5-\mathrm{HT}_{2}$ receptors are decreased in people with acute mania.

\section{Declaration of interest}

None.
Although extensive evidence has accumulated to support the role of serotonin (5-hydroxytryptamine, 5-HT) in major depression, ${ }^{1-3}$ the precise nature of alterations in the 5-HT system that underlie manic symptoms still remains elusive. For instance, the studies of cerebrospinal fluid 5-hydroxyindoleacetic acid (5-HIAA) levels, platelet 5-HT uptake or tritiated imipramine binding sites in people with mania have yielded inconsistent results (see Shiah \& Yatham $^{4}$ for a review). Neuroendocrine studies have reported unaltered prolactin responses to buspirone and dl-fenfluramine, growth hormone responses to sumatriptan, blunted prolactin responses to d-fenfluramine and enhanced cortisol responses to ipsapirone and 5-hydroxytryptophan in people with mania compared with healthy controls. ${ }^{4}$ Taken together, these studies suggest a reduction in presynaptic 5 -HT activity, enhanced postsynaptic $5-\mathrm{HT}_{1 \mathrm{~A}}$ receptor and likely $5-\mathrm{HT}_{2}$ receptor sensitivity, and unaltered $5-\mathrm{HT}_{1 \mathrm{D}}$ receptor sensitivity in mania. ${ }^{4}$ These studies, however, were limited by the fact that they provide information about 5-HT activity in the hypothalamic region only and not in other brain regions. Although numerous positron emission tomography (PET) studies have assessed brain $5-\mathrm{HT}_{2}$ receptors in people with major depression, ${ }^{1,2,5}$ no study to date measured brain $5-\mathrm{HT}_{2}$ receptors in people with acute mania. The purpose of the present study, therefore, was to assess brain $5-\mathrm{HT}_{2}$ receptor density in drug-free or drug-naive people with acute mania in comparison with healthy individuals using $\left[{ }^{18} \mathrm{~F}\right]$ setoperone with PET.

\section{Method}

\section{Participants}

Individuals with current mania $(n=10)$ between the ages of 18 and 65, who fulfilled DSM-IV criteria for bipolar I disorder manic episode and were able to give informed consent were recruited for the study. ${ }^{6}$ All study participants were assessed by a structured clinical interview for DSM-IV diagnosis (SCID). ${ }^{7}$ The DSM-IV diagnosis of mania was arrived at by the consensus of a research team based on information from an unstructured clinical interview as well as SCID. The severity of manic symptoms in participants was assessed by the Young Mania Rating Scale (YMRS). ${ }^{8}$

Participants were either medication naive or psychotropic medication free for at least 2 weeks (6 weeks free for fluoxetine) with the exception of lorazepam prior to the PET scan. Patients with an Axis I comorbidity were excluded as were the individuals with a history of alcohol or drug misuse within the previous 6 months. Those with current major medical illnesses, and women of childbearing potential who were pregnant or not taking contraceptive measures were also excluded.

We also recruited healthy controls $(n=10)$ matched for age (within 6 years) and gender with the individuals with mania. The controls were assessed by a structured clinical interview for DSM-IV diagnosis non-patient version (SCID-NP) ${ }^{9}$ to determine lifetime history of a psychiatric diagnosis. The controls had no lifetime history of psychiatric diagnosis or family history of a mood disorder. All participants in the control group were medication free for at least 6 weeks and had no history of any major medical illnesses. Women of childbearing age who were pregnant or not taking contraceptive measures were excluded.

\section{PET procedure}

The procedure for scanning at our centre has been described previously. ${ }^{1,10}$ Briefly, individuals were escorted to the PET suite by a research coordinator. Each participant had a transmission scan for $10 \mathrm{~min}$ for attenuation correction for PET images. The $\left[{ }^{18} \mathrm{~F}\right]$ setoperone was synthesised as previously described and each participant had 4 to $7 \mathrm{mCi}$ of $\left[{ }^{18} \mathrm{~F}\right]$ setoperone injected intravenously. Individuals were then scanned with PET camera ECAT/953B (Siemens, Knoxville, TN, USA) for $110 \mathrm{~min}$ as previously described.

All study procedures were approved by the clinical research ethics board of the University of British Columbia and a written informed consent was obtained from all study participants. 


\section{Data analysis}

\section{Demographic and clinical variables}

Student's $t$-tests were used to examine the differences in age between individuals with mania and controls. Relationships between $5-\mathrm{HT}_{2}$ receptor binding potential and YMRS scores were assessed using Pearson's correlation coefficient. All tests were twotailed, with significance set at $P<0.05$.

\section{5- $\mathrm{HT}_{2}$ receptor binding potential}

The rationale and methods for determining $5-\mathrm{HT}_{2}$ receptor binding potential have been described previously in detail elsewhere. ${ }^{1}$ Briefly, cerebellum was used as a reference region and the region/ cerebellum ratios from scans during the pseudo-equilibrium period (70 to $110 \mathrm{~min}$ post-injection) were used to compute $5-\mathrm{HT}_{2}$ receptor binding potential images for each participant. Previous studies have shown that the binding potential estimated using the ratio method correlates well with the other invasive and non-invasive methods, ${ }^{11}$ and this approach has been used in a number of other studies to estimate $5-\mathrm{HT}_{2}$ receptor binding potential. $^{1,12,13}$ Statistical parametric mapping (SPM5; Wellcome Department of Cognitive Neurology, Institute of Neurology, London; www.fil.ion.ucl.ac.uk/spm/software) software run on Matlab 7 (Mathworks Inc, Natick, MA, USA) was used for aligning frames from 70 to $110 \mathrm{~min}$ to create a mean image for each participant. The mean image was then coregistered to each person's magnetic resonance (MR) image. Each participant's PET and MR images were normalised to the standard coordinate frame (Montreal Neurological Institute (MNI) template) used in SPM5. Then a $5-\mathrm{HT}_{2}$ receptor binding potential image was created for each participant by dividing each pixel in the normalised mean image with that image's average cerebellar value. A mean activity value from two large regions of interest (one on the right and one on the left) drawn on three contiguous cerebellar slices was used as that image's average cerebellar value.

In order to assess the relationship between $5-\mathrm{HT}_{2}$ receptor binding potential and age, we extracted the $5-\mathrm{HT}_{2}$ receptor binding potential values for frontal, temporal and parietal grey matter regions. The Pick_Atlas program (Wake Forest University School of Medicine, Winston-Salem, NC, USA; www.ansir. wfubmc.edu) run on Matlab 7 was used to create a grey matter mask for frontal, temporal, and parietal cortical regions. The mask for each cortical region was applied to the $5-\mathrm{HT}_{2}$ receptor binding potential images of each participant and the mean for each cortical grey matter region was extracted.

\section{SPM analysis}

Since $5-\mathrm{HT}_{2}$ receptor binding potential significantly declined with age in both individuals with mania and controls, the differences in $5-\mathrm{HT}_{2}$ receptor binding potential between participants with mania and healthy individuals was computed using age as a covariate with the SPM5. A $12 \mathrm{~mm}$ Gaussian filter was used to smooth the binding images before SPM analysis was performed. The grey matter threshold was set at $130 \%$ of the mean image intensity as this threshold eliminated most white matter voxels and included most grey matter voxels. In addition to examining the significance of difference in $5-\mathrm{HT}_{2}$ receptor binding potential for each voxel between the two groups, we also computed the significance of clusters of contiguous voxels in which the difference in $5-\mathrm{HT}_{2}$ receptor binding potential exceeded a threshold of $z=2.57$ corresponding to $P=0.01$. The method implemented in SPM5 calculates the significance of clusters using cluster criteria that takes into account the number of contiguous voxels. The corrected cluster significance was set at $P<0.05$.

\section{Results}

Ten people with mania (three males and seven females) and ten controls (three males and seven females) participated in the study. The details of clinical characteristics and demographics for the ten people with mania are presented in Table 1.

Of the ten people with mania, seven were drug naive and the other three were drug free (one for more than 3 years, one for more than 2 weeks, and one had sertraline discontinued about 2 weeks prior to the baseline PET scan). Seven participants were in their first manic episode and the other three had one to ten previous manic episodes. Eight of the ten had no previous depressive episodes but one had one episode and the other had about ten previous depressive episodes. The duration of the current manic episode for individuals ranged from 1 to 8 weeks. The mean YMRS was 27.1 (s.d.=8.3). There was no significant difference in age between people with mania (mean 34, s.d. $=12.4)$ and controls (mean 32.5, s.d. $=13.71)(P=0.8)$.

As expected, there was a significant negative correlation between age and the $5-\mathrm{HT}_{2}$ receptor binding potential (frontal $r=-0.81$; temporal $r=-0.85$; parietal $r=-0.71 ; P<0.001$ for all regions examined) and this correlation was similar in both groups.

Given that age had a significant negative correlation with $5-\mathrm{HT}_{2}$ receptor binding potential, we assessed difference in $5-\mathrm{HT}_{2}$ receptor binding potential between people with mania and controls using age as a covariate. The SPM analysis using age as a covariate

Table 1 Sociodemographic and clinical characteristics of the ten participants with acute mania

\begin{tabular}{|c|c|c|c|c|c|c|}
\hline Participant number & Age, years & $\begin{array}{l}\text { Young Mania Rating } \\
\text { Scale score on scan day }\end{array}$ & Drug status & $\begin{array}{l}\text { Duration of current } \\
\text { episode, weeks }\end{array}$ & $\begin{array}{l}\text { Previous depressive } \\
\text { episodes, } n\end{array}$ & $\begin{array}{l}\text { Previous manic } \\
\text { episodes, } n\end{array}$ \\
\hline \multicolumn{7}{|l|}{ Female } \\
\hline 1 & 59 & 23 & Naive & 2 & 0 & 0 \\
\hline 2 & 25 & 24 & 2 weeks free & 3 & 10 & 10 \\
\hline 3 & 21 & 28 & $>3$ years free & 4 & 0 & 1 \\
\hline 4 & 25 & 17 & Naive & 8 & 0 & 2 \\
\hline 5 & 32 & 32 & Naive & 2 & 0 & 0 \\
\hline 6 & 52 & 25 & Naive & 1.5 & 0 & 0 \\
\hline 7 & 39 & 48 & Naive & 3 & 0 & 0 \\
\hline \multicolumn{7}{|l|}{ Male } \\
\hline 8 & 29 & 24 & $>2$ weeks free & 5 & 0 & 0 \\
\hline 9 & 30 & 27 & Naive & 4 & 0 & 0 \\
\hline \multirow[t]{2}{*}{10} & 28 & 23 & Naive & 2 & 1 & 0 \\
\hline & Mean 34 (s.d. = 12.4) & Mean 27.1 (s.d. = 8.3) & & & & \\
\hline
\end{tabular}


(a)

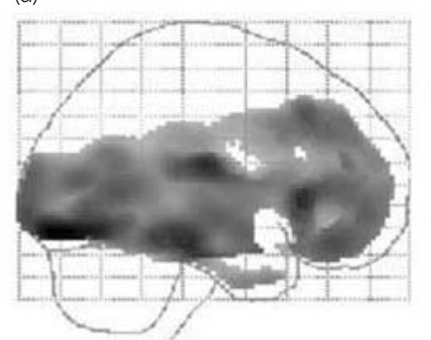

(c)

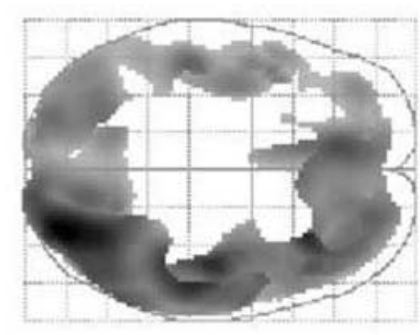

Fig 1 Statistical parametric maps of $t$-values displayed as projections on the sagittal (a), coronal (b) and transverse (c) renderings of the brain.

These projections illustrate regions of significantly decreased $\left[{ }^{18} \mathrm{~F}\right]$ setoperone binding potential in participants with acute mania compared with matched healthy controls.

revealed that binding potential was significantly lower in various cortical regions in people with mania compared with controls. The reductions in binding potential were observed in an extensive cluster of voxels (corrected $P=0.016$ ) bilaterally in cortical regions but changes were more prominent in the right frontal, temporal, parietal and occipital cortical regions (Fig. 1). This cluster had 23974 grey matter voxels. The mean decrease in binding potential for the entire cluster was $19.9 \%$. There were a number of individual voxels in which the reductions in binding potential met significance criteria for false discovery rate $(P<0.025$ after correction for multiple comparisons). The voxels that showed the most significant decrease $(z \geqslant 3.1)$ in binding potential were located in the right fusiform gyrus, right insula, right inferior temporal gyrus, right middle occipital gyrus, right medial frontal gyrus and right middle frontal gyrus. The $5-\mathrm{HT}_{2}$ receptor binding potential remained significantly lower in individuals with mania when the analysis was repeated without controlling for age as a covariate. Further, to exclude the possibility that reductions in brain $5-\mathrm{HT}_{2}$ receptor binding potential in our study participants are a result of reductions in brain grey matter volumes, we compared brain volumes and total grey matter volumes between participants with mania and controls in this study. The results showed no differences in either measure between the two groups.

We found no increase in $5-\mathrm{HT}_{2}$ receptor binding potential in people with mania in any of the brain areas. There was no significant correlation between $5-\mathrm{HT}_{2}$ receptor binding potential and YMRS scores in participants with mania. There was no significant correlation between the duration of manic episode and the $5-\mathrm{HT}_{2}$ receptor binding potential.

\section{Discussion}

Given the difficulty recruiting drug-naive or drug-free people with mania, it is not surprising that this is the first study to examine brain $5-\mathrm{HT}_{2}$ receptors in this population. It took over 4 years to recruit 10 people with acute mania who were drug naive or free and able to provide informed consent. The results showed that $5-\mathrm{HT}_{2}$ receptor binding potential is decreased in frontal, temporal, parietal and occipital cortical regions, suggesting a reduction in brain $5-\mathrm{HT}_{2}$ receptor density in these regions in individuals with mania. Furthermore, consistent with previous studies, the results of this study indicate that $5-\mathrm{HT}_{2}$ receptor density decreases with age.

\section{$5-\mathrm{HT}_{2}$ receptors in platelets and brain}

Previous studies in mood disorders have used platelets as models for brain 5-HT neurons to assess various aspects of 5-HT function. Two previous studies that assessed $5-\mathrm{HT}_{2}$ receptors in mania in platelets reported conflicting findings, with one reporting no change ${ }^{14}$ whereas the other reported an increase in $5-\mathrm{HT}_{2}$ receptor density ${ }^{15}$ in drug-free people with mania compared with healthy controls. However, it must be remembered that although platelet $5-\mathrm{HT}_{2}$ receptor protein is very similar to brain $5-\mathrm{HT}_{2}$ receptor protein, the platelets' $5-\mathrm{HT}_{2}$ receptors are not subjected to the same sort of regulatory mechanisms as brain $5-\mathrm{HT}_{2}$ receptors, which are extensively modulated because of inter-neuronal connections. ${ }^{16}$ The present study and several previous studies have shown that brain $5-\mathrm{HT}_{2}$ receptor density decreases with age but no such correlation was found between platelet $5-\mathrm{HT}_{2}$ receptors and age. ${ }^{15}$ Furthermore, PET studies by our group ${ }^{17}$ and other groups ${ }^{16}$ have shown that the $5-\mathrm{HT}_{2}$ receptor density in platelets does not correlate with brain $5-\mathrm{HT}_{2}$ receptors, thus raising questions about the utility of gleaning information on brain 5-HT status by studying 5-HT binding in platelets.

\section{Limitations}

Some limitations of this study must be considered. First, the number of individuals with mania studied was small. However, we have applied a statistical test that provides a strict control against type I error and hence it is unlikely that the reduction in $5-\mathrm{HT}_{2}$ receptors observed in the participants with mania in this study arose purely by chance.

Second, the study sample was somewhat unusual in that only two of the ten individuals in the mania sample had previous depressive episodes and that two had their first manic episode after age 50. However, it must be remembered that mania is not uncommon after age 50 and that all medical causes of manic symptoms, including substance misuse, were excluded in our participants. Nonetheless, given the smaller sample size and the nature of our study sample, a high degree of caution is warranted in the interpretation of findings as they might not be generalisable to the entire population with mania.

Third, the $5-\mathrm{HT}_{2}$ binding potential in our study was estimated using cortex/cerebellum ratios and not by measuring maximum binding potential $\left(B_{\max }\right)$ and the dissociation constant $\left(K_{\mathrm{d}}\right)$ using arterial input function. Given this, we cannot exclude the possibility that reduced $5-\mathrm{HT}_{2}$ binding potential was a result of changes in $K_{\mathrm{d}}$ and not a result of changes in $B_{\max }$. This, however, is unlikely because previous studies of alteration in receptor binding in other psychiatric conditions have shown changes in $B_{\max }$ and not $K_{\mathrm{d}}$, and thus the reduction in $5-\mathrm{HT}_{2}$ binding potential in our study likely indicates reduced $5-\mathrm{HT}_{2}$ receptors in people with mania. Furthermore, although the two previous platelet studies in mania yielded conflicting findings with regard to changes in $5-\mathrm{HT}_{2}$ receptor density, both studies reported no alteration in $K_{\mathrm{d}}$ for $5-\mathrm{HT}_{2}$ receptors. ${ }^{14,15}$

Fourth, it is possible that the reduction in $5-\mathrm{HT}_{2}$ binding potential is because of an increase in $5-\mathrm{HT}$ in the synaptic space 
in people with acute mania that might be expected to occupy $5-\mathrm{HT}_{2}$ receptors, thus leaving a fewer receptors for the setoperone to bind. This, however, is unlikely as most studies of 5-HT metabolite 5-HIAA levels in people with mania have not reported any consistent increases but rather lower levels compared with healthy controls. Further, PET studies have shown that increases in 5-HT levels in synaptic space with fenfluramine do not result in any changes in $5-\mathrm{HT}_{2}{ }^{18}$ or $5-\mathrm{HT}_{1 \mathrm{~A}}$ receptor binding ${ }^{19,20}$ suggesting that endogenous 5-HT levels do not affect estimates of $5-\mathrm{HT}_{2}$ receptor density with PET.

Fifth, no studies to date assessed the effects of lorazepam on brain $5-\mathrm{HT}_{2}$ receptors and hence it is not possible to exclude the effects of lorazepam on $5-\mathrm{HT}_{2}$ receptors as some of our sample with acute mania but not controls received lorazepam prior to scanning.

\section{Reduction in brain $5-\mathrm{HT}_{2}$ receptor density: a state or trait marker?}

Since some $e^{1,21-23}$ but not all ${ }^{12}$ previous studies that examined brain $5-\mathrm{HT}_{2}$ receptors in people with major depression have reported a reduction in these receptors compared with controls, and given the fact that we found reduced $5-\mathrm{HT}_{2}$ receptors in people with mania, one could argue that a reduction in brain $5-\mathrm{HT}_{2}$ receptors predisposes individuals to both depression as well as mania. However, decreased brain $5-\mathrm{HT}_{2}$ receptor density is unlikely to predispose individuals to depression because several effective antidepressant treatments also down-regulate brain $5-\mathrm{HT}_{2}$ receptors in people with depression, including the tricyclic antidepressant desipramine, ${ }^{10}$ the selective serotonin reuptake inhibitor (SSRI) paroxetine, ${ }^{24}$ the SSRI and $5-\mathrm{HT}_{2}$ antagonist nefazadone, ${ }^{25}$ as well as the somatic treatment electroconvulsive therapy (ECT) (details available from author on request). Given this, we have previously argued that a reduction in brain $5-\mathrm{HT}_{2}$ receptors observed in people with depression is not a cause of depression but rather a compensatory mechanism of the brain to cope with the state of depression. ${ }^{1}$ Such down-regulation of $5-\mathrm{HT}_{2}$ receptors is expected to lead to spontaneous remission of depressive symptoms in some individuals but those people that are not able to mount effective compensatory down-regulation of brain $5-\mathrm{HT}_{2}$ receptors may require treatment with antidepressants or ECT to further down-regulate these receptors to improve from depression. In contrast, antidepressant treatments either induce or worsen manic symptoms in people with bipolar disorder. ${ }^{26-28}$ Given that antidepressant treatments down-regulate brain $5-\mathrm{HT}_{2}$ receptors, the propensity of antidepressants to worsen/induce mania is consistent with the hypothesis that a reduction in brain $5-\mathrm{HT}_{2}$ receptors either predisposes individuals to mania or is a cause of mania. The fact that YMRS scores did not correlate with $5-\mathrm{HT}_{2}$ binding and that treatment of acute mania with valproate does not alter brain $5-\mathrm{HT}_{2}$ receptors ${ }^{29}$ lends support to the hypothesis that decreased $5-\mathrm{HT}_{2}$ receptor density is a trait marker for bipolar disorder. However, studies that assessed the association between $5-\mathrm{HT}_{2}$ receptor polymorphisms and bipolar disorder have yielded no consistent findings. ${ }^{30-33}$

\section{Reduction in brain $5-\mathrm{HT}_{2}$ receptors and increased dopamine in mania}

Regardless of whether a reduction in brain $5-\mathrm{HT}_{2}$ receptors is a state or a trait marker for mania, it is important to reconcile this observation with the fact that drugs that reduce dopamine transmission are effective anti-manic agents whereas drugs that increase dopamine transmission induce or worsen mania. ${ }^{34}$ Interestingly, there is evidence that $5-\mathrm{HT}_{2}$ receptors are located on dopaminergic neurons. ${ }^{35-37}$ Within the $5-\mathrm{HT}_{2}$ receptor family, $5-\mathrm{HT}_{2 \mathrm{~A}}$ receptors facilitate stimulated but not basal dopamine release in the nucleus accumbens and striatum ${ }^{38,39}$ whereas $5-\mathrm{HT}_{2 \mathrm{C}}$ receptors inhibit both basal and stimulated-impulse flow-dependent mesocortical dopamine function. ${ }^{40-42}$ Since the ligand in this study binds to both $5-\mathrm{HT}_{2 \mathrm{~A}}$ and $5-\mathrm{HT}_{2 \mathrm{C}}$ receptors (although it has higher affinity for $5-\mathrm{HT}_{2 \mathrm{~A}}$ receptors), it is likely that reduced binding observed in people with mania represents a reduction in both these receptor subtypes. Accordingly, a reduction in $5-\mathrm{HT}_{2 \mathrm{~A}}$ receptors will have no effect on basal dopamine release whereas a reduction in $5-\mathrm{HT}_{2 \mathrm{C}}$ receptors would be expected to be associated with enhanced dopamine release and transmission. This may explain the efficacy of antidopaminergic drugs for mania.

\section{Brain 5- $\mathrm{HT}_{2}$ receptors and grey matter volume}

Previous studies of people experiencing a first manic episode have not shown any consistent reductions in grey matter volumes compared with age- and gender-matched controls. ${ }^{43}$ Further, a preliminary analysis of our study sample has indicated no changes in either total brain volume or grey matter volume compared with matched controls. Thus, the reduction in $5-\mathrm{HT}_{2}$ receptor density observed in our sample cannot be attributable to changes in grey matter volume. Interestingly, the reduction in $5-\mathrm{HT}_{2}$ receptors observed in our sample was diffuse and included frontal, temporal, parietal and occipital cortical regions although the changes were more prominent in the right limbic regions. A reduction in $5-\mathrm{HT}_{2 \mathrm{C}}$ receptors in these regions is expected to be associated with enhanced dopamine release. Further studies should assess both $5-\mathrm{HT}_{2 \mathrm{C}}$ receptors and the magnitude of dopamine release in acute mania to verify this hypothesis.

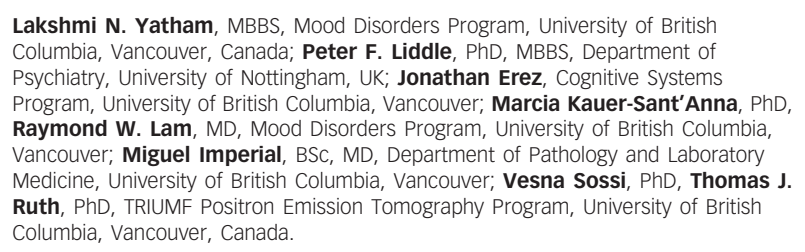

Correspondence: Lakshmi N. Yatham, Professor of Psychiatry, Vice Chair for Research and International Affairs, The University of British Columbia, 2255 , Wesbrook Mall, Vancouver, BC, Canada V6T 2A1. Email:

yatham@exchange.ubc.ca

First received 28 Jul 2008, final revision 31 Aug 2009, accepted 25 Sep 2009

\section{References}

1 Yatham LN, Liddle PF, Shiah IS, Scarrow G, Lam RW , Adam MJ, et al. Brain serotonin2 receptors in major depression: a positron emission tomography study. Arch Gen Psychiatry 2000; 57: 850-8.

2 Meyer JH. Applying neuroimaging ligands to study major depressive disorder. Semin NuCl Med 2008; 38: 287-304.

3 Bhagwagar Z, Whale R, Cowen PJ. State and trait abnormalities in serotonin function in major depression. Br J Psychiatry 2002; 180: 24-8.

4 Shiah IS, Yatham LN. Serotonin in mania and in the mechanism of action of mood stabilizers: a review of clinical studies. Bipolar Disord 2000; 2: 77-92.

5 Bhagwagar Z, Hinz R, Taylor M, Fancy S, Cowen P, Grasby P. Increased 5-HT2A receptor binding in euthymic, medication-free patients recovered from depression: a positron emission study with [C-11] MDL 100,907. Am J Psychiatry 2006; 163: 1580-7.

6 American Psychiatric Association. Diagnostic and Statistical Manual of Mental Disorder, (4th edn) (DSM-IV). APA, 1994.

7 First MB, Spitzer RL, Gibbon M, Williams JBW. Structured Clinical Interview for DSM-IV-TR Axis I Disorders: Research Version, Patient Edition (SCID-I/P). Biometrics Research, 2002. 
8 Young RC, Biggs JT, Ziegler VE, Meyer DA. A rating scale for mania: reliability, validity and sensitivity. Br J Psychiatry 1978; 133: 429-35.

9 First MB, Spitzer RL, Gibbon M, Williams JBW. Structured Clinical Interview for DSM-IV-TR Axis I Disorders: Research Version, Non-Patient Edition (SCID-I/ NP). Biometrics Research, 2002.

10 Yatham LN, Liddle PF, Dennie J, Shiah IS, Adam MJ, Lane CJ, et al. Decrease in brain serotonin 2 receptor binding in patients with major depression following desipramine treatment: a positron emission tomography study with fluorine-18-labeled setoperone. Arch Gen Psychiatry 1999; 56: 705-11.

11 Kapur S, Jones C, DaSilva J, Wilson A, Houle S. Reliability of a simple noninvasive method for the evaluation of 5-HT2 receptors using [18F]-setoperone PET imaging. NuCl Med Commun 1997; 18: 395-9.

12 Meyer JH, Kapur S, Houle S, DaSilva J, Owczarek B, Brown GM, et al. Prefrontal cortex 5-HT2 receptors in depression. An [F-18]setoperone PET imaging study. Am J Psychiatry 1999; 156: 1029-34.

13 Kapur S, Zipursky R, Remington G, Jones C, McKay G, Houle S. PET evidence that loxapine is an equipotent blocker of 5-HT2 and D2 receptors: implications for the therapeutics of schizophrenia. Am J Psychiatry 1997; 154: 1525-9.

14 Velayudhan A, Sunitha TA, Balachander S, Reddy JY, Khanna S. A study of platelet serotonin receptor in mania. Biol Psychiatry 1999; 45: 1059-62.

15 Pandey GN, Pandey SC, Ren XG, Dwivedi Y, Janicak PG. Serotonin receptors in platelets of bipolar and schizoaffective patients: effect of lithium treatment. Psychopharmacologyl 2003; 170: 115-23.

16 Cho R, Kapur S, Du LS, Hrdina P. Relationship between central and peripheral serotonin 5-HT2A receptors: a positron emission tomography study in healthy individuals. Neurosci Lett 1999; 261: 139-42.

17 Yatham LN, Steiner M, Liddle PF, Shiah IS, Lam RW, Zis AP, et al. A PET study of brain 5-HT2 receptors and their correlation with platelet 5-HT2 receptors in healthy humans. Psychopharmacology (Berl) 2000; 151: 424-7.

18 Hirani E, Sharp T, Sprakes M, Grasby P, Hume S. Fenfluramine evokes 5-HT2A receptor-mediated responses but does not displace [11C]MDL 100907: small animal PET and gene expression studies. Synapse 2003; 50: 251-60.

19 Hume S, Hirani E, Opacka-Juffry J, Myers R, Townsend C, Pike V, et al. Effect of 5-HT on binding of [(11)C] WAY 100635 to 5-HT(IA) receptors in rat brain, assessed using in vivo microdialysis nd PET after fenfluramine. Synapse 2001 41: 150-9.

20 De Haes JIU, Harada N, Elsinga PH, Maguire RP, Tsukada H. Effect of fenfluramine-induced increases in serotonin release on [F-18]MPPF]binding. A continuous infusion PET study in conscious monkeys. Synapse 2006; 59: 18-26.

21 Biver F, Wikler D, Lotstra F, Damhaut P, Goldman S, Mendlewicz J. Serotonin 5-HT2 receptor imaging in major depression: focal changes in orbito-insular cortex. Br J Psychiatry 1997; 171: 444-8.

22 Attar-Levy D, Martinot JL, Blin J, Dao-Castellana MH, Crouzel C, Mazoyer B, et al. The cortical serotonin2 receptors studied with positron-emission tomography and [18F]-setoperone during depressive illness and antidepressant treatment with clomipramine. Biol Psychiatry 1999; 45: $180-6$.

23 Messa C, Colombo C, Moresco RM, Gobbo C, Galli L, Lucignani G, et al. 5-HT2A receptor binding is reduced in drug-naive and unchanged in SSRI-responder depressed patients compared to healthy controls: a PET study. Psychopharmacology 2003; 167: 72-8.

24 Meyer JH, Kapur S, Eisfeld B, Brown GM, Houle S, DaSilva J, et al. The effect of paroxetine on 5-HT2A receptors in depression. An [F-18]setoperone PET imaging study. Am J Psychiatry 2001; 158: 78-85.

25 Mischoulon D, Dougherty DD, Bottonari KA, Gresham RL, Sonawalla SB, Fischman AJ, et al. An open pilot study of nefazodone in depression with anger attacks: relationship between clinical response and receptor binding. Psychiat Res 2002; 116: 151-61.
26 Leverich GS, Altshuler LL, Frye MA, Suppes T, McElroy SL, Keck PE, et al. Risk of switch in mood polarity to hypomania or mania in patients with bipolar depression during acute and continuation trials of venlafaxine, sertraline, and Bupropion as adjuncts to mood stabilizers. Am J Psychiatry 2006; 163: 232-9.

27 Post RM, Altshuler LL, Leverich GS, Frye MA, Nolen WA, Kupka RW, et al. Mood switch in bipolar depression: comparison of adjunctive venlafaxine, bupropion and sertraline. Br J Psychiatry 2006; 189: 124-31.

28 Yatham LN, Calabrese JR, Kusumakar V. Bipolar depression: criteria for treatment selection, definition of refractoriness, and treatment options. Bipolar Disord 2003; 5: 85-97.

29 Yatham LN, Liddle PF, Lam RW, Adam MJ, Solomons K, Chinnapalli M, et al. A positron emission tomography study of the effects of treatment with valproate on brain 5-HT2A receptors in acute mania. Bipolar Disord 2005; 7: $53-7$.

30 Ranade SS, Mansour H, Wood J, Chowdari KV, Brar LK, Kupfer DJ, et al. Linkage and association between serotonin $2 A$ receptor gene polymorphisms and bipolar I disorder. Am J Med Genet B 2003; 121B: 28-34.

31 Serretti A, Lilli R, Lorenzi C, Smeraldi E. No association between serotonin-2A receptor gene polymorphism and psychotic symptomatology of mood disorders. Psychiat Res 1999; 86: 203-9.

32 Bonnier B, Gorwood P, Hamon M, Sarfati Y, Boni C, Hardy-Bayle MC. Association of 5-HT2A receptor gene polymorphism with major affective disorders. The case of a subgroup of bipolar disorder with low suicide risk. Biol Psychiatry 2002; 51: 762-5.

33 Mahieu B, Souery D, Lipp O, Mendelbaum K, Verheyen G, DeMaertelaer V, et al. No association between bipolar affective disorder and a serotonin receptor (5-HT2A) polymorphism. Psychiat Res 1997; 70: 65-9.

34 Silverstone T. Dopamine in manic depressive illness. A pharmacological synthesis. J Affect Disord 1985; 8: 225-31.

35 EberleWang K, Mikeladze Z, Uryu K, Chesselet MF. Pattern of expression of the serotonin(2C) receptor messenger RNA in the basal ganglia of adult rats. J Comp Neurol 1997; 384: 233-47.

36 Ward RP, Dorsa DM. Colocalization of serotonin receptor subtypes 5-HT2A, 5-HT2C, and 5-HT6 with neuropeptides in rat striatum. J Comp Neurol 1996; 370: 405-14.

37 Doherty MD, Pickel VM. Ultrastructural localization of the serotonin $2 \mathrm{~A}$ receptor in dopaminergic neurons in the ventral tegmental area. Brain Res 2000; 864: 176-85.

38 Schmidt CJ, Fadayel GM, Sullivan CK, Taylor VL. 5-Ht(2)-Receptors exert a state-dependent regulation of dopaminergic function - studies with Mdl-100,907 and the amphetamine analog, 3,4-methylenedioxymethamphetamine. Eur J Pharmacol 1992; 223: 65-74.

39 Schmidt CJ, Fadayel GM. Regional effects of MK-801 on dopamine release. Effects of competitive NMDA or 5-HT2A receptor blockade. J Pharmacol Exp Ther 1996; 277: 1541-9.

40 Di Giovanni G, De Deurwaerdere P, Di Mascio M, Di Matteo V, Esposito E, Spampinato $U$. Selective blockade of serotonin-2C/2B receptors enhances mesolimbic and mesostriatal dopaminergic function: a combined in vivo electrophysiological and microdialysis study. Neuroscience 1999; 91: 587-97.

41 Di Matteo V, Di Giovanni G, Di Mascio M, Esposito E. SB 242 084, a selective serotonin(2C) receptor antagonist, increases dopaminergic transmission in the mesolimbic system. Neuropharmacology 1999; 38: 1195-205.

42 Di Matteo M, Di Giovanni G, Di Mascio M, Esposito E. Biochemical and electrophysiological evidence that RO 60-0175 inhibits mesolimbic dopaminergic function through serotonin(2C) receptors. Brain Res 2000; 865: 85-90.

43 Yatham LN, Lyoo IK, Liddle P, Renshaw PF, Wan D, Lam RW, et al. A magnetic resonance imaging study of mood stabilizer- and neuroleptic-naive firstepisode mania. Bipolar Disord 2007; 9: 693-7. 